\title{
Penentuan Bonus Tahunan Menggunakan Metode Simple Multi Attribute Rating Technique
}

\author{
Karolina Sitorus ${ }^{1}$, Dedih ${ }^{2 *}$, Arif Budimansyah $\mathbf{P}^{3}$ \\ ${ }^{1,2,3}$ Sistem Informasi, STMIK Horizon Karawang \\ Email: dedih.horizon.krw@horizon.ac.id
}

\begin{abstract}
In an organization or company employees are the most important element. Therefore there are many companies that give appreciation or appreciation to their employees, this aims to motivate employees to improve their work performance. Giving bonuses is one of the strategies that many companies use to reward employees who have worked and satisfy the company. An annual bonus is a variable compensation payment, usually in cash, which is given to employees if the company's annual performance exceeds predetermined financial and non-financial targets. The size of the bonus is usually expressed as a percentage and base salary and may have a minimum. PT Graha Bumi Hijau is a company engaged in tissue production. Where each year PT Graha Bumi Hijau gives an annual bonus to each of its employees, this bonus is called the Key Performance Indicators (KPI). In this company, there are 13 criteria that have been set namely work discipline, responsibility, initiative, creativity, ability to consider and make decisions, adaptability, attitudes toward superiors, impressions of behavior, motor skills, physical conditions, the amount of work produced and the quality of the work produced. But in determining the annual employee bonus is done by collecting data on the results of employee achievement, this method requires less effective time, so that the possibility of errors in the final results of the determination of the annual bonus does not meet the criteria set by the company. Because of that problem, a decision support system was made to facilitate the leaders in calculating the bonus using the SMART Method. And the results of this study create an annual bonus decision support system application using the SMART method assessed based on 13 criteria.
\end{abstract}

Keywords: Application of tourism spot selection, method SMART

\begin{abstract}
Abstrak
Dalam sebuah organiasi atau perusahan karyawan merupakan elemen yang paling utama. Oleh karena itu banyak sekali perusahaan yang memberikan apresiasi atau penghargaan pada karyawannya, ini bertujuan untuk memotivasi karyawan supaya dapat meningkatkan prestasi kerjanya. Pemberian bonus adalah suatu hak perusahaan untuk mengapresiasi prestasi karyawan dalam mengabdikan diri pada perusahaan. Bonus tahunan dapat diberikan perusahaan kepada karyawan karena perusahaan sudah dapat keuntungan.pemberian ini bisa berupa uang tunai yang dihitung dari persentase gaji pokok. PT Graha Bumi Hijau merupakan perusahaan yang bergerak dibidang produksi tissu. Dimana tiap tahunnya PT Graha Bumi Hijau memberikan bonus tahunan kepada tiap karyawannya, bonus ini dimanakan Key Performance Indicators (KPI). dalam perusahaan ini, ada 13 kriteria yang sudah ditetapkan yaitu disiplin kerja, tanggung jawab, inisiatif, kreatifitas, kemampuan mempertimbangkan dan mengambil keputusan, kemampuan adaptasi, sikap terhadap atasan, kesan dari tingkah laku, kecakapan motoris, kondisi fisik, jumlah pekerjaan yang dihasilkan dan mutu hasil kerja yang dihasilkan. Tetapi dalam penentuan bonus tahunan karyawan ini dilakukan dengan cara mengumpulkan data-data hasil pencapaian karyawan tersebut, cara ini membutuhkan waktu yang kurang efektif, sehingga kemungkinan kesalahan dalam hasil akhir dari penentuan bonus tahunan tidak memenuhi kriteria yang sudah ditetapkan oleh perusahaan. Oleh karena permasalahan itu maka dibuatlah satu sistem penunjang keputusan yang mempermudah pimpinan dalam perhitungan bonus tersebut dengan menggunakan Metode Simple Multi Attribute Rating Technique (SMART). Dan hasil dari penelitian ini terciptanya suatu aplikasi sistem penunjang keputusan bonus tahunan dengan menggunakan metode SMART dinilai berdasarkan 13 kriteria
\end{abstract}

Kata Kunci: Sistem Penunjang Keputsan, Bonus, Metode SMART

Jurnal Interkom: Jurnal Publikasi Ilmiah Bidang Teknologi Informasi dan Komunikasi

Volume 16 Nomor 04 Bulan Januari - Tahun 2022 


\author{
Article History : \\ Received 14, Januari, 2022 \\ Revised 17, Januari, 2022 \\ Accepted 18, Januari, 2022

\section{Corresponding Author:} \\ Nama Penulis: Dedih, \\ Departement: Sistem Informasi, \\ Instansi: STMIK Horizon Karawang, \\ Alamat. Jl Pangkal Perjuangan Km. 1 Bypass Karawang \\ Email Penulis. dedih.horizon.krw@horizon.ac.id
}

\section{Pendahuluan}

Dalam sebuah organiasi atau perusahan karyawan merupakan elemen yang paling utama. Oleh karena itu banyak sekali perusahaan yang memberikan appresiasi atau penghargaan pada karyawannya, ini bertujuan untuk memotivasi karyawan supaya dapat meningkatkan prestasi kerjanya. Dalam pemberian bonus kepada karyawan oleh perusahaan merupakan salah satu bukti penghargaan dari perusahaan agar memacu motivasi karyawan untuk dapat lebih meningkatkan kinerjanya. Bonus yaitu suatu pemberian dari perusahaan ke karyawan karena sudah bekerja melebih target produksi (Fisabilillah,2015). Sedangkan, Bonus tahunan adalah sebuah pembayaran kompensasi variabel, biasanya dalam bentuk uang tunai, yang diberikan kepada karyawan jika kinerja tahunan perusahaan melebihi target keuangan dan non keuangan yang telah ditentukan. Dalam pemberian bonus pada umumnya dihitung dari gaji (Charolina Yanthi , 2016).

PT. Graha Bumi Hijau merupakan perusahaan yang bergerak dibidang produksi tissu. Dimana tiap tahunnya PT. Graha Bumi Hijau memberikan bonus tahunan kepada tiap karyawannya, bonus ini dimanakan Key Performance Indicators (KPI). Dalam pemberian bonus ini dilakukan berdasarkan penilaian dari kinerja karyawan beberapa guna untuk menentukan berapa jumlah bonus yang akan diterima. Tetapi dalam penentuan bonus tahunan karyawan ini dilakukan dengan cara mengumpulkan data-data hasil pencapaian karyawan tersebut, cara ini membutuhkan waktu yang kurang efektif, sehingga kemungkinan kesalahan dalam hasil akhir dari penentuan bonus tahunan tidak memenuhi kriteria yang sudah ditetapkan oleh perusahaan. Untuk menghasilkan keputusan yang logis dan transparan diperlukan suatu metode yang mampu memberikan solusi dalam penetuan bonus tahunan karyawan sehingga tidak ada pihak-pihak yang merasa dirugikan. Dalam standar menilai kinerja karyawan ada 6 aspek kunci. Standar kinerja tersebut adalah sebagai berikut : hasil kerja, pengetahuan pekerjaan, inisiatif, kecekatan mental, sikap, disiplin waktu dan absensi, tingkat ketepatan waktu dan tingkat kehadiran (Sutrisno, 2010). Namun dalam perusahaan ini, ada 13 kriteria yang sudah ditetapkan yaitu disiplin kerja, tanggung jawab, inisiatif, kreatifitas, kemampuan mempertimbangkan dan mengambil keputusan, kemampuan adaptasi, sikap terhadap atasan, kesan dari tingkah laku, kecakapan motoris, kondisi fisik, jumlah pekerjaan yang dihasilkan dan mutu hasil kerja yang dihasilkan. Sistem Penunjang Keputusan adalah sistem yang mampu memberikan kemampuan solusi dalam pemecahan masalah. Sistem ini dapat digunakan sebagai alat bantu pengambilan keputusan dirancang untuk meningkatkan efektifitas dan efisiensi kerja pengguna dalam proses pengambilan keputusan (Turban, 2015). Pada penelitian ini, metode yang digunakan adalah metode SMART 
(Simple Multi Attribute Rating Technique). Metode SMART sudah digunakan dalam penelitian pemilihan karyawan tetap $(\mathrm{H}$ Priatna, 2016), seleksi penerima bantuan sosial warga masyarakat terdampak covid 19 (Hutagalung, 2021), pemilihan jenis sapi bagi peternak sapi potong (Pangaribuan, 2019), sehingga metode SMART ini bisa juga digunakan untuk penentuan bonus tahunan pada PT. Graha Bumi Hijau.

\section{Tinjauan Pustaka}

\subsection{Bonus}

Bonus adalah upah tambahan di luar gaji atau upah sebagai hadiah atau perangsang; gaji, upah ekstra yang dibayarkan kepada karyawan(KBBI, 2022).

Bonus adalah bukan merupakan bagian dari upah, melainkan pembayaran yang diterima pekerja dari hasil keuntungan perusahaan atau karena pekerja menghasilkan hasil kerja lebih besar dari target produksi yang normal atau karena peningkatan produktivitas(Surat Kemenaker, 1990).

Bonus dapat diberikan pengusaha kepada pekerja/buruh atas keuntungan perusahaan (Peraturan Pemerintah, 2015).

\subsection{Sistem Penunjang Keputusan}

Sistem penunjang keputusan didefinisikan sebagai sistem berbasis komputer yang terdiri dari komponenkomponen yang saling berinteraksi, yaitu: sistem bahasa, sistem pengetahuan, dan sistem pemrosesan masalah (Turban, 2010).

\subsection{Sistem Simple Multi Attribute Rating Technique (SMART)}

Menurut Kustiyahningsih, Anamisa, dan Syafa'ah (2013), SMART merupakan metode pengambilan keputusan yang multiatribut. Teknik pembuatan keputusan multiatribut ini digunakan untuk membantu stakeholder dalam memilih antara beberapa alternatif. Setiap alternatif terdiri dari sekumpulan atribut dan setiap atribut mempunyai nilai-nilai, nilai ini dirata-rata dengan skala tertentu. Setiap atribut mempunyai bobot yang menggambarkan seberapa penting ia dibandingkan dengan atribut lain. Sistem penunjang

\section{Metode Penelitian}

\subsection{Bahan Penelitian}

Bahan peneltian diambil dari studi literatur berupa buku, jurnal, serta wawancara dan semua data yang berkaitan data laporan penentuan bonus tahunan karyawan di PT Graha Bumi Hijau.

\subsection{Metode Sistem Simple Multi Attribute Rating Technique (SMART)}

Adapun metode yang digunakan dalam penelitian ini adalah metode SMART. Dengan SMART pembobotan atribut dilakukan dengan dua langkah yaitu :

1. Mengurutkan kepentingan suatu atribut dari level terburuk ke level terbaik.

2. Membuat perbandingan rasio kepentingan setiap atribut dengan atribut lain dibawahnya.

Adapun langkah - langkah dari metode SMART sebagai berikut :

a) Menentukan jumlah kriteria.

b) Melakukan Normalisasi

$$
\text { Normalisasi }=\frac{w_{j}}{\sum w_{j}}
$$

Dimana :

$w_{j}=$ Bobot suatu kriteria

$\sum w_{j}=$ Total bobot semua kriteria

c) Memberikan nilai kriteria untuk setiap alternatif

d) Hitung nilai utility untuk setiap kriteria masing-masing

$$
u_{i}\left(a_{i}\right)=100 \frac{\left(C_{\text {outi }}-C_{\text {min }}\right)}{\left(C_{\max }-C_{\min }\right)} \%
$$

Dimana : 
$u_{i}\left(a_{i}\right)=\quad$ Nilai utility kriteria ke-1 untuk kriteria ke-i.

$C_{\max }=$ Nilai kriteria maksimal.

$\begin{array}{ll}C_{\min } & =\text { Nilai kriteria minimal. } \\ C_{\text {outi }} & =\text { Nilai kriteria ke-i. }\end{array}$

e) Hitung nilai akhir masing-masing.

$$
u\left(a_{i}\right)=\sum_{J=1}^{m} w_{j} u_{i}\left(a_{i}\right)
$$

Dimana :

$w_{j}=$ Nilai pembobotan kriteria ke-j dan $\mathrm{k}$ kriteria.

$u\left(a_{i}\right)=$ Nilai utility kriteria ke-i untuk kriteria ke-i.

\section{Hasil dan Pembahasan}

Dalam penentuan bonus tahunan karyawan ini ditentukan berdasarkan kriteria- kriteria yang sudah ditetapkan oleh perusahaan terdiri dari 13 kriteria yang ditunjukan pada tabel di tabel 1. Sedangkan data sampel karyawan yang di ambil sebanyak 15 orang. Adapun tahapan metode SMART yaitu menentukan jumlah kriteria, menentukan normalisasi, memberikan nilai kriteria untuk setiap alternatif, menghitung nilai kriteria untuk setiap alternatif dan menghitung nilai akhir.

\subsection{Menentukan Jumlah Kriteria}

Dalam penentuan jumlah kriteria dapat dilihat dalam tabel 1 dibawah ini :

Tabel 1. Kriteria yang digunakan

\begin{tabular}{lllll}
\hline No. & Kriteria & Kategori & Nilai & Bobot \\
\hline & & Istimewa & 5 & \\
& & Baik & 4 & \\
1. $\quad \begin{array}{l}\text { Disiplin kerja } \\
\text { = K1 }\end{array}$ & Cukup & 3 & $20 \%$ \\
& & Sedang & 2 & \\
& & Kurang & 1 & \\
& & Tstimewa & 5 & \multirow{2}{*}{$15 \%$} \\
2. $\quad$ Janggung $=$ K2 & Baik & 4 &
\end{tabular}

Cukup 3

Sedang 2

Kurang 1

Istimewa 5

Baik 4

3. $\quad$ Inisiatif $=\mathrm{K} 3$ Cukup 3

Sedang 2

Kurang 1

Istimewa 5

4. Kreatifitas $=$ Baik 4

Sedang 2

$30 \%$

Kurang 1

Kemampuan

Istimewa 5

mempertimba Baik 4

5. ngkan dan Cukup 3

$10 \%$

keputusan $=$ Sedang 2

K5

Kurang 1

Istimewa 5

Baik 4

6. $\quad \begin{aligned} & \text { Kemampuan } \\ & \text { adaptasi }=\mathrm{K} 6\end{aligned}$ Cukup 3

$10 \%$

Sedang 2

Kurang 1

Istimewa 5

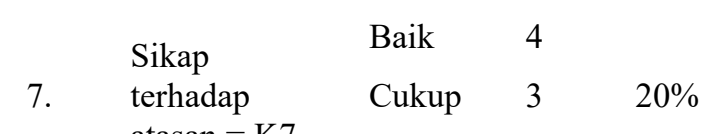

atasan $=$ K7 $\quad$ Sedang 2

Kurang 1

Istimewa 5

Sikap Baik 4

8. $\quad$ terhadap teman kerja $=$ Cukup 3

$10 \%$

K8 Sedang 2

Kurang 1

Kesan dari

Istimewa 5

9. $\quad$ tingkah laku $=$

Baik 4

$10 \%$

Cukup 3

Sedang 2 


\begin{tabular}{|c|c|c|c|c|}
\hline \multirow{6}{*}{10.} & \multirow{6}{*}{$\begin{array}{l}\text { Kecakapan } \\
\text { motoris = K10 }\end{array}$} & Kurang & 1 & \multirow{6}{*}{$10 \%$} \\
\hline & & Istimewa & 5 & \\
\hline & & Baik & 4 & \\
\hline & & Cukup & 3 & \\
\hline & & Sedang & 2 & \\
\hline & & Kurang & 1 & \\
\hline \multirow{5}{*}{11.} & \multirow{5}{*}{$\begin{array}{l}\text { Kondisi fisik = } \\
\text { K11 }\end{array}$} & Istimewa & 5 & \multirow{5}{*}{$10 \%$} \\
\hline & & Baik & 4 & \\
\hline & & Cukup & 3 & \\
\hline & & Sedang & 2 & \\
\hline & & Kurang & 1 & \\
\hline \multirow{5}{*}{12.} & \multirow{5}{*}{$\begin{array}{l}\text { Jumlah } \\
\text { pekerjaan } \\
\text { yang } \\
\text { dihasilkan } \\
\text { K12 }\end{array}$} & Istimewa & 5 & \multirow{5}{*}{$30 \%$} \\
\hline & & Baik & 4 & \\
\hline & & Cukup & 3 & \\
\hline & & Sedang & 2 & \\
\hline & & Kurang & 1 & \\
\hline \multirow{5}{*}{13.} & \multirow{5}{*}{$\begin{array}{l}\text { Mutu hasil } \\
\text { kerja yang } \\
\text { dihasilkan = } \\
\text { K13 }\end{array}$} & Istimewa & 5 & \multirow{5}{*}{$15 \%$} \\
\hline & & Baik & 4 & \\
\hline & & Cukup & 3 & \\
\hline & & Sedang & 2 & \\
\hline & & Kurang & 1 & \\
\hline
\end{tabular}

\subsection{Melakukan Normalisasi}

Untuk melakukan normalisasi digunakan rumus berikut :

Dimana :

$$
\text { Normalisasi }=\frac{w_{j}}{\sum w_{j}}
$$

$w_{j}=$ Bobot suatu kriteria

$\sum w_{j}=$ Total bobot semua kriteria

Tabel 2. Normalisasi

\begin{tabular}{lll}
\hline No. & Kriteria & Normalisasi \\
\hline 1. & K1 & $20 / 200=0.1$ \\
2. & K2 & $15 / 200=0.075$ \\
3. & K3 & $10 / 200=0.05$ \\
4. & K4 & $30 / 200=0.15$ \\
5. & K5 & $10 / 200=0.05$ \\
6. & K6 & $10 / 200=0.05$ \\
\hline
\end{tabular}

\begin{tabular}{lll}
\hline 7. & K7 & $20 / 200=0.1$ \\
8. & K8 & $10 / 200=0.05$ \\
9. & K9 & $10 / 200=0.05$ \\
10. & K10 & $10 / 200=0.05$ \\
11. & K11 & $10 / 200=0.05$ \\
12. & K12 & $30 / 100=0.15$ \\
13. & K13 & $15 / 100=0.075$ \\
\hline
\end{tabular}

\subsection{Memberikan Nilai Kriteria Untuk Setiap Alternatif}

Data yang didapat hasil wawancara yang telah dilakukan untuk nilai kriteria 10 sampel karyawan adalah dapat dilihat di tabel 3.

Tabel 3. Penilaian untuk setiap alternatif

\begin{tabular}{|c|c|c|c|c|c|c|c|c|c|c|c|c|c|c|}
\hline \multirow[b]{2}{*}{ No. } & \multirow[b]{2}{*}{ Nama Karyawan } & \multicolumn{13}{|c|}{ Kriteria } \\
\hline & & $\begin{array}{l}\mathbf{K}_{m} \\
\mathbf{d}\end{array}$ & $\begin{array}{l}\mathbf{K}_{n} \\
2\end{array}$ & $\begin{array}{l}\mathbf{K} \\
3 \\
\end{array}$ & $\begin{array}{l}\mathbf{K}_{m} \\
4\end{array}$ & $\begin{array}{l}\mathbf{K} \\
\mathbf{5}\end{array}$ & $\begin{array}{l}\mathbf{K}_{n} \\
6\end{array}$ & $\begin{array}{l}\mathbf{K}_{n} \\
z\end{array}$ & $\begin{array}{l}\mathbf{K}_{m} \\
\&\end{array}$ & $\begin{array}{l}\mathbf{K}_{n} \\
2\end{array}$ & $\begin{array}{l}\mathrm{K} \\
10\end{array}$ & $\begin{array}{l}\text { K } \\
\text { ll }\end{array}$ & $\begin{array}{l}\mathrm{K} \\
12\end{array}$ & $\begin{array}{l}\mathrm{Kl} \\
13\end{array}$ \\
\hline 1. & Karyawan 1 & 3 & 3 & 4 & 3 & 4 & 4 & 4 & 4 & 4 & 4 & 3 & 3 & 3 \\
\hline 2. & Karyawan 2 & 4 & 4 & 5 & 4 & 4 & 4 & 4 & 4 & 4 & 4 & 3 & 4 & 4 \\
\hline 3. & Karyawan 3 & 4 & 3 & 4 & 4 & 4 & 4 & 3 & 4 & 4 & 4 & 4 & 4 & 4 \\
\hline 4. & Karyawan 4 & 5 & 4 & 4 & 4 & 4 & 3 & 4 & 4 & 4 & 4 & 4 & 5 & 4 \\
\hline 5. & Karyawan 5 & 5 & 5 & 4 & 4 & 4 & 4 & 3 & 4 & 4 & 4 & 4 & 5 & 4 \\
\hline 6. & Karyawan 6 & 4 & 4 & 4 & 4 & 4 & 4 & 3 & 3 & 3 & 4 & 4 & 5 & 4 \\
\hline 7. & Karyawan 7 & 5 & 5 & 4 & 4 & 4 & 4 & 4 & 4 & 4 & 3 & 3 & 5 & 4 \\
\hline 8. & Karyawan 8 & 5 & 5 & 5 & 5 & 4 & 4 & 4 & 4 & 4 & 3 & 3 & 4 & 4 \\
\hline 9. & Karyawan 9 & 4 & 4 & 4 & 5 & 5 & 5 & 4 & 4 & 4 & 4 & 5 & 5 & 4 \\
\hline 10. & Karyawan 10 & 4 & 4 & 4 & 5 & 4 & 4 & 4 & 4 & 4 & 4 & 4 & 5 & 5 \\
\hline
\end{tabular}

\subsection{Menghitung Nilai Utility Dari Setiap} Kriteria

Untuk dapat mengitung nilai utility maka kita menggunakan rumus :

Dimana :

$$
u_{i}\left(a_{i}\right)=100 \frac{\left(C_{\text {outi }}-C_{\text {min }}\right)}{\left(\boldsymbol{C}_{\text {max }}-\boldsymbol{C}_{\min }\right)} \%
$$

$u_{i}\left(a_{i}\right)=\quad$ Nilai utility kriteria ke-1 untuk kriteria ke-i.

$C_{\max }=$ Nilai kriteria maksimal.

$\begin{array}{ll}C_{\min } & =\text { Nilai kriteria minimal } \\ C_{\text {outi }} & =\text { Nilai kriteria ke-i. }\end{array}$

Cara untuk mendapatkan nilai utility sebagai berikut Untuk Karyawan 1 :

\section{Kriteria 1}




$$
\begin{aligned}
u_{K 1}\left(a_{1}\right) & =100 \frac{3-1}{5-1} \% \\
& =100(2 / 4) \% \\
& =100(0.5) \% \\
& =\mathbf{5 0}
\end{aligned}
$$

\section{Kriteria 2}

$$
\begin{aligned}
u_{K 1}\left(a_{1}\right) & =100 \frac{3-1}{5-1} \% \\
& =100(2 / 4) \% \\
& =100(0.5) \% \\
& =\mathbf{5 0}
\end{aligned}
$$

\section{Kriteria 3}

$$
\begin{aligned}
u_{K 3}\left(a_{3}\right) & =100 \frac{4-1}{5-1} \% \\
& =100(3 / 4) \% \\
& =100(0.75) \% \\
& =75
\end{aligned}
$$

\section{Kriteria 4}

$$
\begin{aligned}
u_{K 3}\left(a_{3}\right) & =100 \frac{4-1}{5-1} \% \\
& =100(3 / 4) \% \\
& =100(0.75) \% \\
& =75
\end{aligned}
$$

\section{Kriteria 5}

$$
\begin{aligned}
u_{K 5}\left(a_{5}\right) & =100 \frac{4-1}{5-1} \% \\
& =100(3 / 4) \% \\
& =100(0.75) \% \\
& =75
\end{aligned}
$$

\section{Kriteria 6}

$$
\begin{aligned}
u_{K 6}\left(a_{6}\right) & =100 \frac{4-1}{5-1} \% \\
& =100(3 / 4) \% \\
& =100(0.75) \% \\
& =75
\end{aligned}
$$

\begin{tabular}{|c|c|c|c|c|c|c|c|c|c|c|c|c|c|c|}
\hline \multirow[b]{2}{*}{ No. } & \multirow[b]{2}{*}{ Nama Karyawan } & \multicolumn{13}{|c|}{ Kriteria } \\
\hline & & $\underset{d}{\mathbf{K}}$ & & $\begin{array}{l}\mathbf{K}_{n} \\
3\end{array}$ & $\frac{\mathbf{K}_{m}}{4}$ & $\frac{\mathbf{K}_{m}}{\mathbf{5}}$ & $\begin{array}{l}\mathbf{K}_{m} \\
6\end{array}$ & $\frac{\mathbf{K}_{m}}{\mathrm{z}}$ & $\begin{array}{l}\mathbf{K}_{m} \\
\&\end{array}$ & $\begin{array}{l}\mathbf{K} \\
2\end{array}$ & $\begin{array}{l}\mathrm{K} \\
10\end{array}$ & $\begin{array}{l}\mathrm{K} \\
\mathrm{ll}\end{array}$ & $\begin{array}{l}\mathrm{K} \\
12\end{array}$ & $\begin{array}{l}\mathrm{K} \\
13\end{array}$ \\
\hline 1. & & 50 & 50 & 75 & 50 & 75 & 75 & 75 & 75 & 75 & 75 & 50 & 50 & 50 \\
\hline . & Karyawan 2 & 75 & 75 & 100 & 75 & 75 & 75 & 75 & 75 & 75 & 75 & 50 & 75 & 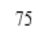 \\
\hline 3. & & 75 & 50 & 75 & 75 & 75 & 75 & 50 & 75 & 75 & 75 & 75 & 75 & 75 \\
\hline 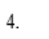 & $\mathrm{K}$ & 100 & 75 & 75 & 75 & 75 & 50 & 75 & 75 & 75 & 75 & 75 & 100 & 75 \\
\hline 5. & Karyawan 5 & 0 & 100 & 75 & 75 & 75 & 75 & 50 & 75 & 75 & 75 & 75 & 100 & 75 \\
\hline . & Karyau & 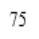 & 75 & 75 & 75 & 75 & 75 & 50 & 50 & 50 & 75 & 75 & 100 & 75 \\
\hline 7. & Karyawa & 00 & 100 & 75 & 75 & 75 & 75 & 75 & 75 & 75 & 50 & 50 & 100 & 75 \\
\hline 8. & & 0 & 100 & 100 & 100 & 75 & 75 & 75 & 75 & 75 & 50 & 50 & 75 & 75 \\
\hline 9. & & 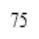 & 75 & 75 & 100 & 100 & 100 & 75 & 75 & 75 & 75 & 100 & 100 & 075 \\
\hline 10 & Karyawan 10 & 75 & 75 & 75 & 100 & 75 & 75 & 75 & 75 & 75 & 75 & 75 & 100 & 0 \\
\hline
\end{tabular}

\section{7. $\quad$ Kriteria 7}

$$
\begin{aligned}
u_{K 7}\left(a_{7}\right) & =100 \frac{4-1}{5-1} \% \\
& =100(3 / 4) \% \\
& =100(0.75) \% \\
& =75
\end{aligned}
$$

\section{Kriteria 8}

$$
\begin{aligned}
u_{K 8}\left(a_{8}\right) & =100 \frac{4-1}{5-1} \% \\
& =100(3 / 4) \% \\
& =100(0.75) \% \\
& =75
\end{aligned}
$$

\section{Kriteria 9}

$$
\begin{aligned}
u_{K 9}\left(a_{9}\right) & =100 \frac{4-1}{5-1} \% \\
& =100(3 / 4) \% \\
& =100(0.75) \%
\end{aligned}
$$

$$
=75
$$

\section{Kriteria 10}

$$
\begin{aligned}
u_{K 10}\left(a_{10}\right) & =100 \frac{4-1}{5-1} \% \\
& =100(3 / 4) \% \\
& =100(0.75) \% \\
& =75
\end{aligned}
$$

\section{Kriteria 11}

$$
\begin{aligned}
u_{K 11}\left(a_{11}\right) & =100 \frac{3-1}{5-1} \% \\
& =100(2 / 4) \% \\
& =100(0.5) \% \\
& =\mathbf{5 0}
\end{aligned}
$$

12. Kriteria 12

$$
\begin{aligned}
u_{K 12}\left(a_{12}\right) & =100 \frac{3-1}{5-1} \% \\
& =100(2 / 4) \% \\
& =100(0.5) \% \\
& =\mathbf{5 0}
\end{aligned}
$$

13. Kriteria 13

$$
\begin{aligned}
u_{K 13}\left(a_{13}\right) & =100 \frac{3-1}{5-1} \% \\
& =100(2 / 4) \% \\
& =100(0.5) \% \\
& =\mathbf{5 0}
\end{aligned}
$$

Cara untuk melakukan perhitungan karyawan 2 sampai karyawan 10 sama seperti mengikuti perhitungan utility karyawan 1 sehingga di dapat tabel 4.

Tabel 4. Hasil Nilai Utility Tiap Alternatif

\subsection{Menghitung Nilai Akhir dan Melakukan Perengkingan}

Untuk dapat Setelah nilai utility tiap alternatif di dapat, selanjutnya melakukan perkalian untuk tiap alternatif terhadap bobot kriteria dan menjumlahkan untuk hasil akhir perhitungan dengan cara : 
Dimana :

$$
u\left(a_{i}\right)=\sum_{J=1}^{m} w_{j} u_{i}\left(a_{i}\right)
$$

$w_{j}=$ Nilai pembobotan kriteria ke-j dan k kriteria.

$u\left(a_{i}\right)=$ Nilai utility kriteria ke-i untuk kriteria ke-i.

Perhitungan untuk :

$$
\begin{aligned}
\text { Karyawan 1 } & (50 \times 0.1)+(50 \times 0.075)+ \\
& (75 \times 0.05)+(50 \times 0.15)+ \\
& (70 \times 0.05)+(75 \times 0.05)+ \\
& (75 \times 150.1)+(75 \times 0.05+ \\
& (75 \times 0.05)+(75 \times 0.05)+ \\
& (50 \times 0.05)+\left(\begin{array}{lll}
50 \times & \times & 0.15
\end{array}\right)+ \\
& (50 \times 0.075) \\
= & \mathbf{6 0}
\end{aligned}
$$

Untuk perhitungan nilai akhir karyawan 2 sampai 10 dapat mengikuti langkah perhitungan karyawan 1, sehingga di dapat nilai seperti tertera di tabel 5 .

\begin{tabular}{lll}
\multicolumn{3}{l}{ Tabel 5 . Hasil Nilai Akhir } \\
\hline No. & Nama Karyawan & Total Nilai \\
\hline 1. & Karyawan 1 & $60 \%$ \\
2. & Karyawan 2 & $75 \%$ \\
3. & Karyawan 3 & $71 \%$ \\
4. & Karyawan 4 & $80 \%$ \\
5. & Karyawan 5 & $81 \%$ \\
6. & Karyawan 6 & $74 \%$ \\
7. & Karyawan 7 & $81 \%$ \\
8. & Karyawan 8 & $82 \%$ \\
& & \\
9. & Karyawan 9 & $86 \%$ \\
10. & Karyawan 10 & $84 \%$ \\
\hline
\end{tabular}

Setelah nilai akhir di dapat selanjutnya dilakukan perkalian dengan jumlah gaji yang diterima, untuk menenntukan jumlah bonus yang akan diterima oleh tiap karyawan.

Tabel 6 . Hasil Jumlah Bonus

\begin{tabular}{lllll}
\hline $\begin{array}{l}\text { No. } \\
\text { Nama } \\
\text { Karyawan }\end{array}$ & $\begin{array}{l}\text { Gaji } \\
\text { Pokok } \\
\text { (Rp) }\end{array}$ & $\begin{array}{l}\text { Total } \\
\text { Nilai }\end{array}$ & $\begin{array}{l}\text { Jumlah } \\
\text { Bonus } \\
\text { (Rp) }\end{array}$ \\
\hline 1. & Karyawan 1 & $4.954 .000,-$ & $60 \%$ & $2.972 .400,-$ \\
2. & Karyawan 2 & 4.954 .000$, & $75 \%$ & $3.715 .500,-$ \\
3. & Karyawan 3 & 4.954 .000$, & $71 \%$ & $3.498 .760,-$ \\
4. & Karyawan 4 & 4.954 .000$, & $80 \%$ & $3.963 .200,-$ \\
5. & Karyawan 5 & 4.954 .000$, & $81 \%$ & $3.994 .162,-$ \\
6. & Karyawan 6 & 4.954 .000$, & $74 \%$ & $3.653 .575,-$ \\
7. & Karyawan 7 & 4.954 .000$, & $81 \%$ & $3.994 .163,-$ \\
8. & Karyawan 8 & 4.954 .000$, & $82 \%$ & $4.056 .086,-$ \\
9. & Karyawan 9 & 4.954 .000$, & $86 \%$ & $4.272 .825,-$ \\
10. & Karyawan & 4.954 .000$, & $84 \%$ & $4.179 .938,-$ \\
\hline & 10 & & & \\
\hline
\end{tabular}

\section{Penutup}

Sistem penunjang keputusan penentuan bonus tahunan menggunakan metode SMART untuk menghitung besaran bonus yang diterima yang terdiri dari 10 alternatif dan 13 kriteria sedangkan untuk penilaian bobot menggunakan skala $1-5$ sehingga menghasilkan nilai peringkat, untuk hasil hasil akhirnya dikalikan dengan besaran gaji pokok yang diterima oleh tiap

\begin{tabular}{l|l|}
\multicolumn{1}{l|}{ karyawan. } & \\
\hline Daftar Pustaka & \\
& \\
[1] Fisabilillah and D. A. Irawati,
\end{tabular} "Sistem Pendukung Keputusan Pemberian Bonus Tahunan Pada Karyawan Dengan Metode FuzzyTopsis," Pros. Semin. Inform. Apl. Polinema 2015, pp. 157-161, 2015.

[2] Y. Charolina, "Sistem Pendukung Keputusan Untuk MenentukanPemberian Bonus Tahunan Menggunakan Metode Fuzzy Logic Tipe Mamdani," $J$. Teknol. Inf., vol. 12, pp. 42-53, 2016.

[3] M. S. Prof. Dr. H. Edy Sutrisno, Manajemen Sumber daya Manusia. 
Jakarta: Kencana, 2009.

[4] E. Turban, J. E. Aronson, and T. Liang, Decision Support Systems and Intelligent Systems, 7th ed. New Delhi: Prentice Hall Of India, 2005.

[5] H. Priatna, J. Mulyana, T. Informatika, and T. Informatika, "Perbandingan Metode Smart Dan Simple Additive Weighting (Saw) Dalam Menentukan Karyawan Tetap Berbasis Web," UNSIKA Syntax J. Inform., vol. 5, no. 1, pp. 53-85, 2016.

[6] B. T. S. Hutagalung Elida Tuti; Lubis, Juanda Hakim, "Penerapan Metode SMART dalam Seleksi Penerima Bantuan Sosial Warga Masyarakat Terdampak COVID19," J. Media Inform. Budidarma, vol. 5, no. Vol 5, No 1 (2021): MIB Januari 2021, pp. 170-185, 2021, doi: $10.30865 / \mathrm{mib} . v 5 i 1.2618$.

[7] G. Ramadhan Pangaribuan, A. Perdana Windarto, W. Prima Mustika, and A. Wanto, "Sistem Pendukung keputusan Pemilihan Jenis Sapi bagi Peternak Sapi Potong dengan Metode Smart," J. Ilmu Komput. dan Inform., vol. 6341, no. April, 2019.

[8] "Kamus Besar Bahasa Indonesia." 2022, [Online]. Available: https://kbbi.web.id/bonus.

[9] Mentri Tenaga Kerja Republik Indonesia, "Se-07/Men/1990 Tentang Pengelompokan Upah," 1990.

[10] R. of I. MInistry of Manpower, "Peraturan Pemerintah Republik Indonesia Nomor 78 Tahun 2015." Jakarta, 2015.

[11] M. I. Ukkas, H. Pratiwi, and D. Purnamasari, "Sistem Pendukung Keputusan Penentuan Supplier Bahan Bangunan Menggunakan Metode Smart (Simple Multi Attribute Rating Technique) Pada
Toko Bintang Keramik Jaya," Sebatik, vol. 16, no. 1, pp. 34-43, 2016 , doi: 10.46984/sebatik.v16i1.73. 